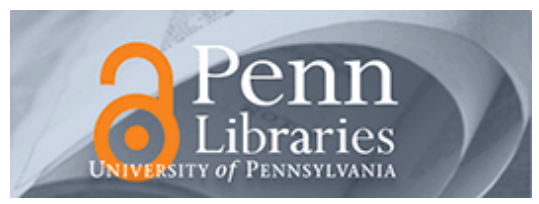

University of Pennsylvania

ScholarlyCommons

Departmental Papers (EES)

December 2004

\title{
The development of a diatom-based transfer function along the Pacific coast of eastern Hokkaido, northern Japan-an aid in paleoseismic studies of the Kuril subduction zone
}

\author{
Yuki Sawai \\ National Institute of Advanced Industrial Science and Technology \\ Benjamin P. Horton \\ University of Pennsylvania, bphorton@sas.upenn.edu \\ Tamotsu Nagumo \\ Nippon Dental University
}

Follow this and additional works at: https://repository.upenn.edu/ees_papers

\section{Recommended Citation}

Sawai, Y., Horton, B. P., \& Nagumo, T. (2004). The development of a diatom-based transfer function along the Pacific coast of eastern Hokkaido, northern Japan-an aid in paleoseismic studies of the Kuril subduction zone. Retrieved from https://repository.upenn.edu/ees_papers/40

Postprint version. Published in Quaternary Science Reviews, Volume 23, Issues 23-24, 2004, pages $2467-2484$.

Publisher URL: http://dx.doi.org/10.1016/j.quascirev.2004.05.006

This paper is posted at ScholarlyCommons. https://repository.upenn.edu/ees_papers/40

For more information, please contact repository@pobox.upenn.edu. 


\title{
The development of a diatom-based transfer function along the Pacific coast of eastern Hokkaido, northern Japan-an aid in paleoseismic studies of the Kuril subduction zone
}

\begin{abstract}
This paper provides a dataset to develop a diatom-based transfer function, which is applicable to paleoseismic studies at southwestern Kuril subduction zone, northern Japan. Modern diatom samples were collected from five transects from saltmarshes of Lakes Akkeshi and Onnetoh along the Pacific coast of eastern Hokkaido. The relationships between diatom species and environmental variables were elucidated by canonical correspondence analysis (CCA) and partial CCAs. Partial CCAs associated with Monte Carlo permutation tests show that elevation accounts for a significant portion of the total variance in the diatom data. Therefore, statistically significant transfer functions quantifying the relationship between modern diatom assemblages and elevation were developed using weighted averaging partial least squares and applied to fossil diatom assemblages from Lake Onnetoh. The reconstructed curve of elevations contains five emergence and four submergence events and the transfer functions calculated the amplitude of four of the emergence events to be at least $1 \mathrm{~m}$. The results are consistent with paleoecological data produced by previous studies. If these events represent uplift associated with interplate earthquake and subsidence during an interseismic period along the Kuril subduction zone, transfer functions of eastern Hokkaido can contribute to reconstruction of the recurrence intervals and the amplitude of earthquakes.
\end{abstract}

\section{Comments}

Postprint version. Published in Quaternary Science Reviews, Volume 23, Issues 23-24, 2004, pages

2467-2484.

Publisher URL: http://dx.doi.org/10.1016/j.quascirev.2004.05.006 
The development of a diatom-based transfer function along the Pacific coast of eastern Hokkaido, northern Japan - an aid in paleoseismic study of the Kuril subduction zone

Yuki Sawai $^{* 1}$, Benjamin P. Horton ${ }^{* 2}$, and Tamotsu Nagumo ${ }^{* 3}$

*1 Active Fault Research Center, Geological Survey of Japan, National Institute of Advanced Industrial Science and Technology, Site C7 1-1-1 Higashi, Tsukuba 305-8567 Japan

*2 Department of Earth and Environmental Science, University of Pennsylvania, Philadelphia, PA 19104-6316, USA

${ }^{* 3}$ Department of Biology, The Nippon Dental University, Fujimi, Chiyoda-ku, Tokyo 102-8159, Japan

Headings: Quantitative relative sea-level reconstruction in Japan

*Corresponding author: Yuki SAWAI, yuki.sawai@aist.go.jp 
Abstract

This paper provides a dataset to develop a diatom-based transfer function, which is applicable to paleoseismic studies at southwestern Kuril subduction zone, northern Japan. Modern diatom samples were collected from five transects from saltmarshes of Lakes Akkeshi and Onnetoh along the Pacific coast of eastern Hokkaido. The relationships between diatom species and environmental variables were elucidated by canonical correspondence analysis (CCA) and partial CCAs. Partial CCAs associated with Monte Carlo permutation tests show that elevation accounts for a significant portion of the total variance in the diatom data. Therefore, statistically significant transfer functions quantifying the relationship between modern diatom assemblages and elevation were developed using weighted averaging partial least squares and applied to fossil diatom assemblages from Lake Onnetoh. The reconstructed curve of elevations contains at fives emergence and four submergence events and the transfer functions calculated the amplitude of four of the emergence events to be at least $1.0 \mathrm{~m}$. The results are consistent with paleoecological data produced by previous studies. If these events represent uplift associated with interplate earthquake and subsidence during an interseismic period along the Kuril subduction zone, transfer functions of eastern Hokkaido can contribute to reconstruction of the recurrence intervals and the amplitude of earthquakes.

Keywords: diatoms, transfer function, salt marsh, earthquakes, Hokkaido 


\section{Introduction}

The process of subduction is associated with large earthquakes at plate boundaries (Thatcher, 1984; Savage and Thatcher, 1992). Before an earthquake, the upper continental plate locks with underlying oceanic plate at the seaward edge of the subduction-zones. The locked zones between both plates cause downward creeping of the upper plate (interseismic strain). During the earthquake, the stress is released (elastic deformation) and these processes can produce geologic evidences in coastal areas. (e.g. Atwater, 1997; Nelson et al., 1996a). Along the northwest Pacific coast of America, seismic cycles during the Holocene are expected to record relative sea-level (RSL) changes in coastal deposits which consist of intercalation of brackish-marine mud with brackish-freshwater peat (Atwater and Hemphill-Haley, 1997; Nelson et al., 1996b; Shennan et al., 1998). Furthermore, on the southeast of the Kuril subduction zone, recent studies attribute Holocene RSL changes reconstructed from estuarine deposits to plate-boundary earthquakes in the Holocene (Atwater et al., in press; Sawai, 2001a; Sawai et al., 2002), even though historical records of the past 200 years give no evidence of great earthquakes at eastern Hokkaido, near the Kuril subduction zone. If the RSL changes are the product of plate-boundary earthquakes on the Kuril subduction zone, then accurate reconstructions of RSL changes are required to assess the spatial extent and recurrence intervals of the earthquakes.

One approach to the study of post-glacial RSL change has been to use microfossil assemblages (e.g. diatoms) that are preserved in a range of coastal sedimentary deposits. During the past 50 years, sea-level indicators developed from microfossils have been used extensively to provide reconstructions of Holocene RSL 
change, for the UK, Europe and elsewhere (e.g. Denys and de Wolf, 1999; Shennan and Horton, 2002). However, these microfossil data and their associated RSL reconstructions are subject to errors, which limit the precision of determining both age and elevation. With increasing focus on sea-level changes of shorter period and smaller amplitude, the relative size of these errors become increasingly important. One challenge for studies of Holocene RSL is to limit errors by using the most precise indicators available.

Transfer functions produce precise reconstruction of former sea levels using a statistically based relationship between modern diatom assemblages, their measured relationships to sea level and their fossil counterparts (Gehrels et al., 2001; Horton et al., 1999, 2003; Horton and Edwards, 2003, 2004 in press; Sherrod, 1999; Zong and Horton, 1999). Although numerous studies of microfossils and their relationship to RSL in coastal environments of Japan have been reported (see below), there are ample opportunities to increase knowledge of changes in sea level in the Japanese region using the understanding and techniques developed by other ecologists, limnologists, oceanographers, palynologists and geologists.

This paper, therefore, seeks to document some characteristics of modern environments along the Pacific coastline of eastern Hokkaido, Japan and to develop a diatom-based transfer function for use in paleoseismic interpretations of the southern Kuril subduction zone.

\section{Previous studies in Japan}


Detailed studies of diatoms and their relationship to RSL began in Japan in the 1980s although a few pioneer works had been already published (e.g. Hasegawa, 1976). Their first aims were to establish a coastal diatom classification and to apply this to reconstruct changes in sedimentary environments across marine-freshwater transitions of Holocene deposits (Ando, 1986; Kashima, 1986; Kosugi, 1988). Subsequently, the classifications were used to decipher RSL observations associated with the mid Holocene RSL highstand and the late Holocene RSL fluctuations (e.g. Fujimoto, 1990; Ohira et al., 1994; Umitsu, 1994; Sawai and Kashima, 1996; Yokoyama et al., 1996; Kawase, 198; Sawai and Mishio, 1998; Sato et al., 2001; Sawai, 2001a). A mid Holocene RSL highstand along the coast of eastern Hokkaido is estimated to have occurred between 3000 and $6000{ }^{14} \mathrm{C}$ years ago as indicated by uplifted and buried shells of intertidal bivalves and marine mud-freshwater peat contacts (Maeda et al., 1992; Maeda et al., 1994).

Details of RSL fluctuations after the highstand are recorded by fossil diatom assemblages at Lakes Akkeshi and Onnetoh (Sawai, 2001a; Sawai et al., 2002). Diatom assemblages from estuarine deposits at these sites record at least three cycles of RSL rise and fall in the past 3000 years with recurrence intervals of between 1100 and 300 cal years. Sawai (2001a) and Sawai et al. (2002) concluded that these repetitions of rise and fall were attributed to uplift associated with interplate earthquakes along the Kuril subduction zone. However, the changes in RSL associated with these earthquakes have not been quantitatively analysed. . 
3. Study area

\subsection{Transects}

Five studied transects were selected from two estuaries in Hokkaido, Lakes Akkeshi (transects A, B and C) and Onnetoh (transects D and E) (Fig. 1), which cover a wide range of environmental factors (e.g. tidal range and sedimentary conditions).

Lake Akkeshi is protected from the open sea by a narrow entrance dominated by oyster banks. The lake floor consists mainly of fine sand and mud, and the shore is exposed at the low tide. Saltmarshes occupy the eastern shores of the lake. The spring-tide range is $1.2 \mathrm{~m}$ and the neap-tide range $0.9 \mathrm{~m}$ (Maritime Safety Agency, 1998). The extreme tidal range, between the highest and lowest astronomical tides, is $1.7 \mathrm{~m}$. A 200m transect (Transect A) from the southern saltmarsh, which has a salinities of 5-34ppt, was studied and covers a range of sub-environments from forested upland, high marsh, low marsh to tidal flat. The forested upland is dominated by Alnus japonica and Alnus hirsute (Fig 2). Phragmites communis and Spiraea salicifolia cover the high marsh where sediments are composed of mud (silts and clays). The narrow low marsh is dominated by Triglochin maritimum and Carex subspathacea. The sediments on tidal flats are composed entirely of sand with Zostera marina and Zostera japonica (Fig. 2). Transect B is close to Transect A and covers the same range of sub-environments but also includes the subtidal zone. Vegetation and surface sediments from upland to tidal flat are near-identical to Transect A. The subtidal zones are dominated by Zostera marina and Zostera japonica. Sediments of the subtidal zones are composed of sand but also contain more mud_relative to the tidal flat. Transect $\mathrm{C}$ is about $700 \mathrm{~m}$ long and extends from upland, high marsh, low marsh to 
tidal flat. The upland is forested and dominated by Alnus japonica, Alnus hirsute, and Lysichiton camtschatcense, where sediments are composed of wet soil. The high marsh is dominated by herbaceous plants including Carex spp. and Phragmites communis, whereas the low marsh supports Triglochin maritimum and Carex subspathacea. Sediments on these marshes are composed of mud, and the tidal flat consists entirely of fine sand.

Lake Onnetoh has the similar range of tides as the Lake Akkeshi, however the salinity range is lower (2 to 16ppt). The saltmarshes of Lake Onnetoh are protected from the sea by a sand barrier (Fig. 1). Transect D is located in the southern area of Lake Onnetoh. The sub-environments include upland, high marsh, low marsh and tidal flat. Forested upland is located above the highest high tide level (HHTL). The upland vegetation is characterized mainly by Picea glehnii, and also includes Menziesia pentandra, Abies sachalinensis, and Maianthemum dilatatum. The forest floor consists of moss. The saltmarsh is separated into high and low marshes by tide level and dominant species of vascular plants. The high marsh is between mean high tide level (MHTL) and HHTL (Sawai 2001b). The high marsh contains mainly Phragmites communis, and the downward edge of high marsh is dominated by Eleocharis kamtschatica and Eleocharis acicularis var longiseta. The low marsh is located below HHTL and dominated by Triglochin maritimum and Carex subspathacea. Some vegetation containing Zostera marina and Zostera japonica is found on the tidal flat. Sediments on the tidal flat are composed of mud. Transect $E$ lies near the entrance of Lake Onnetoh. The transect extends from forested upland, high marsh, through salt pond to tidal flat. The upland is dominated by Alnus japonica and Alnus hirsute. 
Sediments on the high marsh consist mainly of humic mud, and are covered by Phragmites communis. The salt pond is isolated from the sea by a sand berm and a narrow outlet connecting to the sea. The tidal flat consists of fine-grained sand.

\subsection{Core site}

The transfer function is applied to fossil diatom assemblages in deposits of Lake Onnetoh to test the applicability of the transfer function for palaeoseismic studies (Fig. 1). The core was obtained from a station near the most landward part of the Transect D. The core comprises alternating brackish-marine inorganic mud and brackish-freshwater peat. The inorganic mud includes seeds of saltmarsh plants, such as Triglochin. maritimum and Carex. subspathacea. The peat contains abundant plant macrofossils, including leaves of Picea glehnii, Hylocomium splendens, and Rhytidiadelphus triquetrus although some samples of peat (about $0.19-0.24 \mathrm{~m}$ and -0.24 m relative to the present MTL) are dominated by fruits of Eleocharis kamtschatica and Scirpus tabernaemontani, which live in freshwater and brackish wetlands (Sawai et al., 2002). Ages of this core were estimated by three radiocarbon assays from seeds, cone scale, and leaves (Table 4) and three tephras: the age of tephra Ta-c2 has been reported as $1600{ }^{14} \mathrm{C}$ yr BP (Ohira et al., 1994) and 2500 cal yr BP (Kelsey et al., 2002); tephra Ta-a as A.D.1739; and tephra Ko-c2 as A.D.1694 (Saiwa et al., 2002).

\section{Methods}

\subsection{Diatom analysis}

We collected modern samples from each transect at the sediment-water 
interface (top 2-3mm of surface sediment) using disposable plastic syringes of $10 \mathrm{ml}$ or a small spatula during low tides. After collection, samples were kept at about $-15^{\circ} \mathrm{C}$ in a freezer. In the laboratory, samples were divided using disposable plastic syringes. The sub-samples were treated using a staining method described by Sawai (2001b). Live and dead diatoms were identified and counted in each prepared slide using an oil immersion microscope (1000 magnification) until approximately 300 dead diatom cells were counted. Fragments consisting of more than half of a diatom valve were included in the count of dead diatoms (Sawai, 2001b). We referred to Krammer $(1982,2000)$, Krammer and Lange-Bertalot (1986, 1988, 1991a, 1991b), Lange-Bertalot (1996, 2001), Patrick and Reimer (1966), Sawai and Nagumo (2003), Round et al. (1990), and Witkowski et al. (2000) for diatom identification.

We apply a training set of modern dead diatom assemblages to the fossil core. A 'living diatom' training set may reflect the most accurate ecological conditions, however, living diatom populations can vary throughout the year in abundance and productivity within the same estuary (Moore and McIntire, 1977; Sabbe, 1993). In our diatom data, counted dead frustules and valves greatly exceed living cells in Hokkaido's lakes and the relative abundance of the total (living + dead) diatoms is almost the same as the abundance of only dead diatom assemblages (Sawai, 2001a). This observation suggests that dead diatom assemblages can account for seasonal variation of living diatoms and be similar to fossil diatom assemblages rather than the living diatom population.

Another critical issues for coastal paleoenvironmental reconstructions using diatom data is the autochthonous/allochthonous problem because daily tides easily 
transport diatom valves and frustules (Simonsen, 1969; Vos and de Wolf, 1993). Sawai (2001b) showed that Paralia sulcata and Cocconeis scutellum could be significant allochthonous components in tidal marsh deposits. Living specimens of Paralia sulcata form long chains (Crawford, 1979). The chains can float and small specimens are transported by the flow of the tide, and trapped during the ebb (Denys, 1999; Hemphill-Haley, 1995a; Nelson et al., 1996b; Sawai, 2001b; Sawai et al., 2002). Cocconeis scutellum lives on seaweed, to which the cells are strongly attached through the raphid valve (R-valve). On death, however, non-attached P-valves become separated from the seaweed, whereas R-valves remain attached by the mucilage. Separated P-valves are transported over long distances by tidal currents, and many valves are incorporated as an allochthonous component of surface sediment assemblages. Only P-valves are entirely and selectively distributed on tidal environments, although its habitat is limited to the seaweed zone (Sawai, 2001b). Thus, in this paper we use a training set of dead diatom species relative to total diatom valves counted excluding Paralia sulcata and P-valves of Cocconeis scutellum.

\subsection{Environmental analysis}

We collected modern samples for environmental analyses (porewater salinity, grain size and organic content) at the same time as the diatom sampling. Porewater was separated by centrifuge from the modern sediment samples. The porewater salinity was measured using salinity refractometer. Grain size was measured by gentle washing through sieves and organic matter contents of the sediments were measured by loss on ignition. All stations were leveled to sea level using a level and staff at regular spatial and temporal intervals throughout the study, and the tide gauge data from Akkeshi 
town was used to standardize elevations with respect to elevation of the lowest tide of each day and the nearest bench mark of the Geographical Survey Institute of Japan (error $\pm 0.10 \mathrm{~m})$.

\subsection{Canonical correspondence analysis}

We studied the relationships between diatom species and environmental variables using canonical correspondence analysis (CCA) (ter Braak, 1986). The independence and relative strength of the major environmental gradients were estimated using a series of partial CCAs to separate the total variation in the diatom data into components which represent: i) the unique contributions of individual environmental variables; ii) the contribution of covariance between variables; and iii) the unexplained variance. The statistical significance of the partial CCAs was determined using a Monte Carlo permutation test. CCA was performed using the computer program CANOCO release 4 (ter Braak and Smilauer, 1998). Only taxa exceeding $3 \%$ were used in the analysis.

\subsection{Quantitative reconstruction techniques}

Numerous transfer functions have been developed to reconstruct quantitatively paleoenvironmental variables. Some of these have a stronger ecological and/or statistical basis than others. Thus, some methods are more appropriate than others for quantifying relationship between diatom assemblages and elevation. The fundamental distinction between existing methods concerns the underlying taxon-environment response model (Birks, 1995). The amount of biological compositional turnover along the environmental gradient of interest (elevation) is used to decide whether linear-based or unimodal-based statistical methods are appropriate 
(Birks, 1995). This was estimated using detrended canonical correspondence analysis (DCCA) with detrending by segments and non-linear rescaling provides an estimate (as the length of DCCA axis one) of the gradient length in relation to elevation in standard deviation (SD) units (Birks, 1995; Korsman and Birks, 1996). If the gradient length is longer than 2 SD units several species will have their optima located within the gradient and unimodal-based methods of regression and calibration are appropriate (Birks, 1995). Detrended canonical correspondence analysis of the training set with elevation as the only environmental variable has produced a gradient length of 6.40 . This indicates a unimodal nature of the diatom abundance data with respect to elevation relative to the present mean tidal level. Thus, unimodal-based methods of regression and calibration were used.

Diatom-based transfer functions have been previously developed using a unimodal-based technique known as weighted averaging (WA) regression and calibration with inverse and classical deshrinking (e.g. Horton et al., 1999; Zong and Horton, 1999). Here we advocate the use of another unimodal-based technique, weighted averaging partial least squares (WA-PLS). There are two main reasons why WAPLS outperforms WA. Firstly, WA suffers from “edge effects” and, therefore, it overestimates optima at the low end and underestimates optima at the high end of the environmental gradient (Birks, 1995). Second, the influences of additional environmental variables to those of interest are ignored in WA even though they are likely to affect the composition and abundance of biological data. WA-PLS uses the interactions between environmental variables to improve predictions. The transfer function for elevation was developed using the program CALIBRATE, release 0.70, 
1997 (Juggins and ter Braak, 1997). The performance of the transfer functions was assessed in terms of root-mean square error of prediction (RMSEP) and squared correlation $\left(r^{2}\right)$ of observed versus predicted values. Root-means square error of prediction indicates prediction errors and $r^{2}$ measures the strength of the relationship of observed versus predicted values. Root-means square error of prediction and $r^{2}$ were calculated as both 'apparent' measures in which the whole training set was used to generate the transfer function and assess the predictive ability, and jack-knifed or 'leave-one-out' measures (ter Braak and Juggins, 1993). Jack-knifing generates a prediction error $\left(\mathrm{RMSEP}_{\text {jack }}\right)$, which is a measure of the overall predictive abilities of the training set.

\section{Results}

\subsection{Diatom assemblages (Figs. 3-5; Table 1)}

We identified 148 taxa from the five modern transects of Lakes Akkeshi and Onnetoh. It is worth noting that Cocconeis scutellum and Paralia sulcata are widely scattered on all transects. The distributions of other dominant diatom species show clear transitions associated among sub-environments. On Transects A and B, freshwater diatoms Diadesmis contenta var. contenta and Eunotia bilunaris dominate in upland, whereas Planothidium delicatulum and Tryblionella compressa are common on tidal flats. Despite this clear contrast, brackish-marine diatoms Caloneis bacillum, Navicula rhynchocephala, and Scolioneis tumida, are common both in high and low marshes and the boundaries between these sub-environments are mixed. The transitions between sub-environments of Transect $\mathrm{C}$ are more distinct than Transects $\mathrm{A}$ 
and B, although brackish diatom Navicula cryptotenella overlaps between high and low marshes. Composition of diatom assemblages on upland and tidal flat of Transect C are similar to Transects A and B.

On Transect D, the high marsh and the low marsh are composed of distinct brackish diatom assemblages, Gyrosigma obscrum and Pseudostaurosira brevistriata, and Gyrosigma scalproides, Navicula cryptotenella and Navicula digtoradiata, respectively. The upland of Transect E is dominated by Pinnularia subrabenhorstii and Planothidium lanceolatum. The assemblage changes from freshwater diatoms on the upland to brackish diatoms on the salt pond, which is composed of Pleuosigma pulchrum and Scolioneis tumida. The tidal flat of Transect E is composed of diatom species such as Planothidium delicatulum that are similar to Transect C.

\subsection{Canonical correspondence analysis}

We use a regional training set (excluding Cocconeis scutellum and Paralia sulcata) from the 5 modern transects to elucidate the relationship between the diatom assemblages and a series of environmental variables. The sample-environment and species-environment biplots show that axes one (eigenvalue $=0.80$ ) is correlated with LOI, elevation and salinity, whilst axes two (eigenvalue $=0.59$ ) is correlated with sand and mud (Fig. 6; Tables 2). Both axes control 15.1\% and 74.6\% of the species-data and species environmental relationships, respectively. Therefore, axis one reflects the major gradient from high marsh plotted on the right (high elevation, LOI and low salinity) to tidal flat plotted on the left (low elevation, LOI and salinity). Axis two reflects a grain-size gradient with sand-dominated station at the top and silt-dominated 
at the bottom of the plot. The sample-environment biplot shows the five study areas occupying a similar ordination space, which suggests that most of the assemblages among sites are compatible with respect to the major environmental gradients. Species characteristic of a particular environment may also be identified on the species- and sites-environment biplot (Fig. 6; Table 1). For example, Diadesmis contenta var. contenta, which is a freshwater and aerophilous diatom, has strong positive correlations with upland sites with high elevation and LOI. Moreover, Tryblionella granulata and Diploneis decipiens var. parallea are related to tidal flat sites with high sand fractions and low elevations.

The five environmental variables account for $20.2 \%$ of the explained variance in the diatom data (Fig. 7a). Partial CCAs (Fig. 7b) show that the total explained variance is composed of $17.1 \%$ (LOI), $15.1 \%$ (elevation), $13.7 \%$ (salinity), $12.0 \%$ (sand fraction) and $9.9 \%$ (mud fraction). The associated Monte Carlo permutation tests indicate that each of these gradients accounts for a significant portion of the total variance in the diatom data ( $\mathrm{p}=0.01,99$ random permutations). Therefore, statistically significant transfer functions quantifying the relationship between modern diatom assemblages and elevation can be developed. However, $32.2 \%$ of the total explained variance of diatom data is accounted for by inter-correlations between environmental variables and, thus, a transfer function for elevation cannot be considered to be completely independent from other variables. Numerous studies have shown a strong relationships of elevation versus substrate, LOI in particular (Horton, 1999. Horton and Edwards, 2004 in press; Horton et al., 1999; 2003 in press; Zong and Horton 1999). Subsequently, for palaeoenvironmental reconstructions, it must be assumed that the 
joint distribution with elevation in the training set is the same as in the fossil set (Le and Shackleton, 1994; Birks, 1995). One striking fact raised by CCA is the large amount of unexplained variation: over $79.8 \%$ total variation of the diatom data remains unexplained. Whether this is due to some overlooked factor (e.g. seasonal variations; Horton and Edwards, 2003) or to a large amount of stochastic variations remains unclear. Nevertheless, the explained percentage is similar to those found in many other biological datasets with a large number of samples with many zero values (Gasse et al., 1995; Jones and Juggins 1995; Zong and Horton, 1999).

\subsection{Diatom-based elevation transfer function}

We developed a transfer function for elevation from 75 species and 78 samples from the 5 study sites (without Paralia sulcata and P-valves of Cocconeis scutellum). WA-PLS produces as many components as there are variables or samples. The first component maximises the covariance between the vector of weighted averages and the environmental variable of interest (elevation). Subsequent components are chosen to maximise the same criterion but must be uncorrelated to earlier components (Birks, 1995). The choice of component for the transfer function depends upon the prediction statistics (RMSEP ${ }_{\text {jack }}$ and $r_{\text {jack }}^{2}$ ) and the principle of parsimony, that is, the lowest component that gives an acceptable model (Horton et al., 2003 in press). Therefore, we have chosen component two because it performs better than components one and three, with modest differences thereafter when jack-knifed errors are considered (Tables 4). Figure 8 shows the relationship between observed and diatom-predicted elevation using component two, which illustrates the strong

performance of the local WA-PLS transfer functions $\left(\operatorname{RMSEP}_{\text {jack }}=0.29 ; r_{\text {jack }}^{2}=0.84\right)$. 
The training set covers a range of elevations from subtidal to upland. Therefore, it is expected to perform well with alternating of brackish (subtidal-high marsh) and freshwater (upland) samples found in the fossil core. However, the transfer function reconstruction for freshwater samples may underestimate relative to brackish samples. This is to be expected as diatoms of aerial habitat (such as upland) are controlled by numerous other environmental variables, such as moisture, extremes of temperature and substrate (Ando 1979, 1981, 1982; Jahansen, 1999).

6. Application to fossil diatom assemblages from Lake Onnetoh

\subsection{Elevation changes reconstructed from Onnetoh core samples}

The changes in elevations at Lake Onnetoh were reconstructed using WA-PLS. The continuous curve of elevations contains five obvious emergence events (Fig. 9). The first emergence, dated 1733-2001 cal. yr BP, records at least $1.0 \mathrm{~m}$ change across the contact between inorganic mud and overlying peat. Subsequently, a clear submergence (at least $1.3 \mathrm{~m}$ ) is recognized surrounding tephra Ta-c2. This submergence was replaced by the second emergence of at least $1.3 \mathrm{~m}$ (Cycle 1). The next cycle of submergence and emergence (Cycle 2) is recorded below the sample dated 1174-1350 cal. yr BP. The amplitude of the event (at least $0.5 \mathrm{~m}$ ) is small relatively to the others. After the Cycle 2, the transfer function shows two sudden submergence and emergence (both amplitudes of at least. $1.0 \mathrm{~m}$ ) cycles (Cycles 3 and 4) around the stratigraphic contact dated 523-315 cal. yr BP. In addition, the latter submergence and emergence (Cycle 4) is found just below two tephras (tephra Ta-a: 
A.D.1739, tephra Ko-c2: A.D.1694). These results are consistent with paleoecological data (diatoms and macro plant fossils) given by Sawai et al. (2002) and Atwater et al. (in press).

\subsection{Implication of reconstructed elevation changes}

Recent studies along the Pacific coasts of eastern Hokkaido have attributed RSL changes in the late Holocene to subsidence during an interseismic period and uplift associated with interplate earthquakes along the Kuril subduction zone (Kelsey et al., 2002; Sawai, 2001a; Sawai et al., 2002). If the RSL history reflects the paleoseismic cycles, the reconstructed elevations given by diatom-based transfer function represent the amplitude of coastal subsidence and uplift events associated with the earthquakes. In such seismic cycles, the net deformation is estimated zero for individual earthquake cycles (Hyndman and Wang, 1995; Hyndman et al., 1995). Thus an equation is suggested which can estimate coseismic or postseismic deformation (amplitude of subsidence or uplift) from the rate of interseismic deformation and the interval of earthquakes on the Cascadia subduction zones (Long and Shennan, 1998). This can be directly applied to Kuril subduction zone:

$$
H=R^{*} I
$$

where $H$ equals the amplitudes of coseismic or postseismic uplift (mm), $R$ the rate of interseismic subsidence accompanied with strain accumulation (mm/year), and $I$ the interval since the last earthquake (years). The present interseismic subsidence rate can be provided by the recent tide-gauge data at Hanasaki, near Onnetoh (average rate of 8 mm/yr: Ozawa et al., 1997). We can calculate the interval value of 160-60 years from the last earthquake event (about A.D.1600, Atwater et al., in press). Despite this 
estimation, well-dated deposits record only four seismic emergence events in the past 2000 years with recurrence intervals of more than 500 cal years (Sawai, 2001a; Sawai et al., 2002). Therefore, there is a clear disagreement between observational data and geological evidence. One possibility is that deformation patterns vary with each earthquake cycles. The other possibility is that changes in rates of interseismic strain accumulation, especially during the preseismic period, result in the difference between the calculated interval value and the geologic record. Studies of diatom analysis across the stratigraphic contacts associated with earthquakes near Cascadia subduction zones may provide good analogues for Hokkaido (e.g. Atwater and Hemphill-Haley, 1997; Hemphill-Haley, 1995b; Long and Shennan, 1998; Shennan et al., 1996, 1998; Sherrod et al., 2000). For example, a reduction of strain accumulation during an interseismic period was suggested by detailed diatom analysis across the stratigraphic contacts in Johns River and Netarts Bay estuaries (Long and Shennan, 1998). If the second possibility were correct, transfer functions of higher resolution at Hokkaido would clarify the detailed changes in interseismic, coseisimic, and postseismic land-levels.

\section{Conclusion}

This study provides new calibration data for quantitative reconstruction of elevation relative to the tidal level at eastern Hokkaido, northern Japan. Canonical correspondence analysis (CCA) and partial CCAs show that diatom assemblages from modern samples have statistically significant relationships with elevation. Therefore, diatom-based transfer functions using weighted averaging partial least squares 
(WA-PLS) were developed. Transfer functions reconstruct an emergence and four cycles of emergence and submergence from fossil diatom assemblages at Lake Onnetoh over the last 2000 years; with three of these cycles having a amplitude of at least $1.0 \mathrm{~m}$. If the cycles are attributed to subsidence and uplift events associated with interplate earthquake at the Kuril subduction zone, transfer functions using the data of this study can contribute to paleoseismic studies.

\section{Acknowledgements}

Brian Sherrod encouraged us to develop Hokkaido’s diatom data for transfer function method. We thank Hiroo Nasu for fruitful collaboration in the Onntoh Research project, Brian Atwater, Masayuki Fujikawa, Yasutaka Ikeda, Kaoru Kashima, Kentaro Misao, Andy Moore, Satoko Odagiri, Yoko Ota, Sun-Cheon Park, Kenji Satake, Hisako Yamato, Koichi Shimokawa, and Chikara Uchida for help in the sample collection, and Alan Hogg and Fiona Petchey for radiocarbon dating. Also we thank two anonymous referees for improving manuscript. The research was supported in part by Grant-in-Aid for Scientific Research from the Japanese Ministry of Education, Science and Culture (no. 10007549, 13007536). 


\section{Reference}

Ando, K., 1979. Moss diatoms in Japan (3). The Japanese Journal of Phycology 27. 153-159. (in Japanese with English abstract)

Ando, K., 1981. Moss diatoms in Japan (4). The Japanese Journal of Phycology 29. 201-207. (in Japanese with English abstract)

Ando, K., 1982. Moss diatoms in Japan (5). The Japanese Journal of Phycology 30. 319-324. (in Japanese with English abstract)

Ando, K., 1986. Holocene paleoenvironments and the highest sea-level based on the diatom assemblages in Munima Lowland, Saitama. The Quaternary Research (Daiyonki-Kenkyuu) 23, 165-174. (in Japanese with English abstract)

Atwater, B.F., 1997. Coastal evidence for great earthquakes in western Washington. U.S. Geological Survey Professional Paper 1560; U.S. Government Printing Office: Washington.

Atwater, B.F., Hemphill-Haley, E., 1997. Recurrence intervals for great earthquakes of the past 3500 years at northeastern Willapa Bay, Washington. U.S. Geological Survey Professional Paper 1576; U.S. Government Printing Office: Washington.

Atwater, B.F., Hemphill-Haley, E., Furukawa, R., Ikeda, Y., Kashima, K., Kawase, K., Kelsey, H.M., Moore, A.L., Nanayama, F., Nishimura, Y., Odagiri, S., Ota, Y., Park, S., Sawai, Y., Satake, K., Shimokawa, K., in press. Seventeenth-century uplift in eastern Hokkaido, Japan. The Holocene

Birks, H.J.B., 1995. Quantitative paleoenvironmetal reconstructions. In: Maddy, D. and Brew, J.S. (eds), Statistical Modelling of Quaternary Science Data, 161-236. Technical Guide No. 5, Quaternary Research Association, Cambridge. 
Crawford, R.M., 1979. Taxonomy and frustular structure of the marine centric diatom Paralia sulcata. Journal of Phycology 15, 200-210.

Denys, L., 1999. A diatom and radiocarbon perspective of the palaeoenvironmental history and stratigraphy of Holocene deposits between Oostende and Nieuwpoort (western coastal plain, Belgium). Geologica Belgica 2, 111-140.

Denys, L., de Wolf, H., 1999. Diatoms as indicators of coastal paleo-environments and relative sea-level change. In: Stoermer, E. F., Smol, J. P. (Eds.), The Diatoms. Applications for the Environmental and Earth Sciences. Cambridge University Press, Cambridge, pp. 277-297.

Fujimoto, K., 1990. Successional reconstruction of late Holocene sea-level fluctuations in Matsushima Bay, northeastern Japan. Geographical Review of Japan 63, 629-652 . (in Japanese with English abstract)

Gasse, F., Juggins, S., Khelifa, L.B., 1995. Diatom-based transfer functions for inferring past hydrochemical characteristics of African lakes. Palaeogeography Palaeoclimatology Palaeoecology 117, 31-54.

Gehrels, W.R., Roe, H.M., Charman, D.J., 2001. Foraminifera, testate amoebae and diatoms as sea-level indicators in UK saltmarshes: a quantitative multiproxy approach. Journal of Quaternary Sciences 16, 201-220.

Hasegawa, Y., 1976. Significance of diatom thanatocoenoses in the Neolithic sea-level change problem. Pacific Geology 11, 1-32.

Hemphill-Haley, E., 1995a. Intertidal diatoms from Willapa Bay, Washington: Application to studies of small-scale sea-level changes. Northwest Science 69, 29-45. 
Hemphill-Haley, E., 1995b. Diatom evidence for earthquake induced subsidence and tsunami 300 yr ago in southern Washington. Geological Society of America Bulletin 107, 367-378.

Horton, B.P., 1999. The contemporary distribution of intertidal foraminifera of Cowpen Marsh, Tees Estuary, UK: implications for studies of Holocene sea-level changes. Palaeogeography, Palaeoclimatology, Palaeoecology Special Issue 149, 127-149.

Horton, B.P., and Edwards, R.J., 2003, Seasonal distributions of foraminifera and their implications for sea-level studies. SEPM (Society for Sedimentary Geology) Special Publication No. 75, 21-30.

Horton, B.P., and Edwards, R.J., 2004 in press. The application of local and regional transfer functions to reconstruct former sea levels, North Norfolk, England. The Holocene.

Horton, B.P., Edward, R.J., Lloyd, J.M., 1999. UK intertidal foraminiferal distributions: implications for sea-level studies. Marine Micropaleontology 36, 205-223.

Horton, B. P., Larcombe, P., Woodroffe, S. E., Whittaker, J. E., Wright, M. W. and Wynn, C., 2003. Contemporary foraminiferal distributions of the Great Barrier Reef coastline, Australia: implications for sea-level reconstructions. Marine Geology, 3320, 1-19

Hyndman, R.D., Wang, K., 1995. The rupture zone of Cascadia great earthquakes from current deformation and the thermal regime. Journal of Geophysical Research 100, 22133-22154. 
Hyndman, R.D., Wang, K., Yamano, M., 1995. Thermal constrains to the seismogenic portion of the southwestern Japan subduction thrust. Journal of Geophysical Research 100, 15373-15392.

Jahansen, 1999. Diatoms of aerial habitats. In: The Diatoms: Application for the environmental and earth sciences, Stoermer EF, Smol JP (eds); Cambridge University Press: Cambridge.

Jones, V.J., Juggins, S., 1995. The construction of diatom-based chlorophyll transfer function and its application at three lakes on Signy Island (marine Antarctic) subject to differing degrees of nutrient enrichment. Freshwater Biology 34, 433-445.

Juggins, S., ter Braak, C.J.F., 1997. CALIBRATE. Department of Geography, University of New Castle.

Kashima, K., 1986. Holocene succession of diatom fossil assemblages in alluvium, and those relations to paleo-geographical changes. Geographical Review of Japan 59, 383-403. (in Japanese with English abstract)

Kawase, K., 1998. Late Holocene paleoenvironmental changes in the Yahagi River lowlands, central Japan. Geographical Review of Japan 71, 411-435. (in Japanese with English abstract)

Kelsey, H., Satake, K., Sawai, Y., Sherrod, B., Shimokawa, K., Shishikura, M., 2002. Late Holocene repeated rapid coastal uplift in eastern Hokkaido. Annual Report on Active Fault and Paleoearthquake Researches, Geological Survey of Japan/AIST, No 2, Sugiyama Y (eds); Geological Survey of Japan: Tsukuba, pp. 223-233. (in Japanese with English abstract) 
Kosugi, M., 1988. Classification of living diatom assemblages as the indicator of environments, and its application to reconstruction of paleoenvironments. The Quaternary Research (Daiyonki-Kenkyuu) 27, 1-20. (in Japanese with English abstract)

Korsman, T., Birks, H.J.B., 1996. Diatom-based water chemistry reconstructions: a comparison of reconstruction techniques. Journal of Paleolimnology 15, 65-77.

Krammer, K. 1982. Observations on the alveoli and areolae of same Naviculaceae. Nova Hedwigia Beih, 73, 55-80.

Krammer, K., 2000. Diatoms of Europe. Diatoms of the European inland waters and comparable habitats. Volume 1. The genus Pinnularia, A.R.G. Ganter Verlag K.G., Ruggell.

Krammer, K., Lange-Bertalot, H., 1986. Süßwasserflora von Mitteleuropa. Bacillariophyceae 1. Teil:Naviculaceae, Gustav Fischer Verlag, Stuttgart.

Krammer, K., Lange-Bertalot, H., 1988. Süßwasserflora von Mitteleuropa.

Bacillariophyceae 2. Teil:Bacillariaceae, Epithemiaceae, Surirellaceae, Gustav Fischer Verlag, Stuttgart.

Krammer, K., Lange-Bertalot, H., 1991a. Süßwasserflora von Mitteleuropa.

Bacillariophyceae 3. Teil:Centrales, Fragilariaceae, Eunotiaceae, Gustav Fischer Verlag, Stuttgart.

Krammer, K., Lange-Bertalot, H., 1991b. Süßwasserflora von Mitteleuropa.

Bacillariophyceae 4. Teil:Achnanthaceae Kritische Ergänzungen zu Navicula (Lineolatae) und Gomphonema, Gustav Fischer Verlag, Stuttgart. Lange-Bertalot, H., 1996. Iconographia Diatomologica. Annotated Diatom 
Micrographs Vol. 2, Koeltz Scientific Books, Königstein.

Lange-Bertalot, H., 2001. Diatoms of Europe. Diatoms of the European inland waters and comparable habitats. Volume 2. Navicula sensu stricto 10 genera separated from Navicula sensu lato Frustulia, A.R.G. Ganter Verlag K.G, Ruggell.

Le, J., Shackleton, N.J., 1994. Estimation of palaeoenvironment by transfer functions: simulation with hypothetical data. Marine Micropaleontology 24, 187-199.

Long, A.J., Shennan, I., 1998. Models of rapid relative sea-level change in Washington and Oregon, USA. The Holocene 8, 129-142.

Maeda, Y., Nakada, M., Matsumoto, E., Matsuda, I., 1992. Crustal tilting derived from Holocene sea-level observations along the east coast of Hokkaido in Japan and upper mantle rheology. Geophysical Research Letters 19, 857-860.

Maeda, Y., Matsuda, I., Nakada, M., Matsushima, Y., Matsumoto, E., Sato, Y., 1994. Holocene sea-level change along the Okhotsk Sea in Hokkaido, Japan -On the theoretical and observational values of the high sea-level stand-. Bulletin of Yamagata University, Natural Science 13, 205-229. (in Japanese with English abstract)

Maritime Safety Agency, 1998. Heisei 11 nen, chouseki hyou (1999 tide tables). Maritime Safety Agency Publication Number 781, volume 1, Maritime Safety Agency Publication, Tokyo.

Moore, W.W., McIntire, C.D., 1977. Spatial and seasonal distribution of littoral diatoms in Yaquina Estuary, Oregon (U.S.A.). Botanica Marina 20, 99-109.

Nelson, A.R., Shennan, I., Long, A.J., 1996a. Identifying coseismic subsidence in tidal-wetland stratigraphic sequences at the Cascadia subduction zone of western 
North America. Journal of Geophysical Research 101, 6115-6135.

Nelson, A.R., Jennings, A.E., Kashima K., 1996b. An earthquake history derived from stratigraphic and microfossil evidence of relative sea-level change at Coos Bay, southern coastal Oregon. Geological Society of America Bulletin 108, 141-154.

Ohira, A., Umitsu, M., Hamade, S., 1994. Late Holocene development of peatlands lands in small alluvial lowlands around Lake Furen, eastern Hokkaido, Japan. The Quaternary Research (Daiyonki-Kenkyuu) 33, 45-50. (in Japanese with English abstract)

Ozawa, S., Hashimoto, M., Tada, T., 1997. Vertical crustal movements in the coastal areas of Japan estimated from tidal observations. Bulletin of the Geographical Survey Institute 43, 1-21.

Patrick, R., Reimer, C., 1966. The diatoms of United States. Exclusive of Alaska and Hawaii. Volume 1. Monograph of The Academy of Natural Sciences of Philadelphia. Number 13, The Academy of Natural Sciences of Philadelphia, Philadelphia.

Round, F.E., Crawford, R.M., Mann, D.G., 1990. The Diatoms. Biology and morphology of the genera, Cambridge University Press, Cambridge.

Sabbe, K., 1993. Short-term fluctuations in benthic diatom numbers on an intertidal sandflat in the Westerschelde estuary (Zeeland, The Netherlands). Hydrobiologia 269/270, 275-284.

Sato, H., Okuno, J., Nakada, M., Maeda, Y., 2001. Holocene uplift derived from relative sea-level records along the coast of western Kobe, Japan. Quaternary Science Reviews 20, 1459-1474. 
Savage, J.C., Thatcher, W., 1992. Interseismic deformation at the Nankai Trough, Japan, subduction zone. Journal of Geophysical Research 97, 11117-11135.

Sawai, Y., 2001a. Episodic emergence in the past 3000 years at the Akkeshi estuary, Hokkaido, northern Japan. Quaternary Research 56, 231-241.

Sawai, Y., 2001b. Distribution of living and dead diatoms in tidal wetlands of northern Japan: relations to taphonomy. Palaeogeography Palaeoclimatology Palaeoecology 173, 125-141.

Sawai, Y., Kashima, K., 1996. Late Holocene relative sea-level changes and reconstruction of paleoenvironment by diatom fossil assemblage analysis in Akkeshi Moor, Hokkaido, northern Japan. Fossil (Kaseki) 61, 21-31. (in Japanese with English abstract)

Sawai, Y., Mishio, W., 1998. Marine transgressions and regressions over the last 3000 years in Akkeshi Moor, Hokkaido, northern Japan. The Quaternary Research (Daiyonki-Kenkyuu) 37, 1-12. (in Japanese with English abstract)

Sawai, Y., Nasu, H., Yasuda, Y., 2002. Fluctuations in relative sea-level during the past 3000 years in the Onnetoh estuary, Hokkaido, northern Japan. Journal of Quaternary Science 17, 607-622.

Sawai, Y. and Nagumo, T., 2003. Diatom (Bacillariophyceae) flora of salt marshes along the Pacific coast of eastern Hokkaido, northern Japan. Bulletin of the Nippon Dental University 32, 93-108.

Shennan, I., Long, A.J., Rutherford, M.M., Green, F.M., Innes, J.B., Lloyd, J.M., Zong, Y., Walker, K. J., 1996. Tidal marsh stratigraphy and the earthquake deformation cycle, I: a 5000 year record of large earthquakes in Washington, USA. 
Quaternary Science Reviews 15, 1023-1059.

Shennan, I., Long, A.J., Rutherford, M.M., Innes, J.B., Green, F.M., Kirby, J.R., Walker, K.J., 1998. Tidal marsh stratigraphy, sea-level change and large earthquakes, II: Submergence events during the last 3500 years at Netarts Bay, Oregon, USA. Quaternary Science Reviews 17, 365-393.

Shennan, I., Horton, B., 2002. Holocene land- and sea-level changes in Great Britain. Journal of Quaternary Science 17, 511-526.

Sherrod, B.L., 1999. Gradient analysis of diatom assemblages in a Puget Sound salt marsh: can such assemblages be used for quantitative paleoecological reconstructions? Palaeogeography, Palaeoclimatology, Palaeoecology 149, 213-226.

Sherrod, B.L., Bucknam, R.C., Leopold, E.B., 2000. Holocene relative sea level changes along the Seattle fault at Restoration point, Washington. Quaternary Research 54, 384-393.

Simonsen, R., 1969. Diatoms as indicators in estuarine environments. Velöffentl. Inst. Meeresforsch. Bremerhaven 11, 287-291.

Stuiver, M., Reimer, P.J., 1993. Extended 14C database and revised CALIB radiocarbon calibration program. Radiocarbon 35, 215-230.

Stuiver, M., Reimer, P.J., Bard, E., Beck, J.W., Burr, G.S., Hughen, K.A., Kromer, B., McCormac, F.G., van der Plicht, J., Spurk, M., 1998. NTCAL98 Radiocarbon age calibration 24,000 - 0 cal BP. Radiocarbon 40, 1041-1083.

Thatcher W., 1984. The earthquake deformation cycle, recurrence, and the time-predictable model. Journal of Geophysical Research 89, 5674-5680. 
ter Braak, C.J.F., 1986. Canonical correspondence analysis: a new eigenvector technique for multivariate direct gradient analysis. Ecology 67, 1167-1179. ter Braak, C.J.F., Juggins, S., 1993. Weighted averaging partial least square regression (WA-PLS) : an improved method for reconstructing environmental variables from species assemblages. Hydrobiologia 269/270. 485-502.

ter Braak, C.J.F., Smilauer, P., 1998. Software for Canonical Community Ordination (version 4). Microcomputer Power, New York.

Umitsu, M., 1994. Late Quaternary environment and landform evolution of riverine coastal Lowlands, Kokon-Shoin, Tokyo. (in Jappanese)

Vos, P.C., De Wolf, H., 1993. Diatoms as a tool for reconstructing sedimentary environments in coastal wetlands; methodological aspects. Hydrobiologia 269/270, 285-296.

Witkowski, A., Lange-Bertalot, H., Metzeltin, D., 2000. Diatom flora of marine coasts I, A.R.G. Gantner Verlag K.G., Ruggell.

Yokoyama, Y., Nakada, M., Maeda, Y., Nagaoka, S., Okuno, J., Matsumoto, E., Sato, H., Matsushima, Y., 1996. Holocene sea-level change and hydro-isostasy along the west coast of Kyushu, Japan. Palaeogeography Palaeoclimatology Palaeoecology 123, 29-47.

Zong, Y., Horton, B.P., 1999. Diatom-based tidal-level transfer functions as an aid in reconstructing Quaternary history of sea-level movements in the UK. Journal of Quaternary Sciences 14, 153-16 
Table 1. List of dominant diatom taxa.

\begin{tabular}{|c|c|c|c|c|c|}
\hline Code $^{1}$ & Diatom species & average $^{2}$ & $\max ^{3}$ & $\min ^{4}$ & $\mathrm{~N}^{5}$ \\
\hline AMHO & Amphora holsatica Hustedt & 4.9 & 14.6 & 0.3 & 10 \\
\hline AMSA & Amphora salina W.Smith & 3.9 & 13.7 & 0.3 & 41 \\
\hline AUCR & Aulacoseira crassipunctata Krammer & 10.4 & 18.7 & 2.2 & 2 \\
\hline CABA & Caloneis bacillum (Grunow) Cleve & 7.1 & 36.8 & 0.3 & 39 \\
\hline CAOR & Caloneis oregonica (Ehrenberg) Patrick & 7.4 & 18.3 & 1.2 & 3 \\
\hline COPU & Cosmioneis pusilla (W.Smith) D.G.Mann \& A.J.Stickle & 3.0 & 15.5 & 0.8 & 7 \\
\hline DICC & Diadesmis contenta var. contenta (Grunow) D.G.Mann & 10.0 & 24.3 & 1.2 & 8 \\
\hline DIDP & Diploneis decipiens var. parallela Cleve & 11.3 & 42.9 & 0.6 & 34 \\
\hline DIMI & Dimmeregramma minor (Gregory) Ralfs & 3.8 & 5.2 & 1.0 & 6 \\
\hline DISM & Diploneis smthii (Brébisson) Cleve & 2.1 & 8.9 & 0.3 & 36 \\
\hline EUBI & Eunotia bilunaris (Ehrenberg) Mills & 14.1 & 42.8 & 1.0 & 7 \\
\hline EUPA & Eunotia paludosa Grunow & 7.4 & 10.1 & 4.4 & 4 \\
\hline EUPP & Eunotia praerupta Ehrenberg & 2.9 & 7.4 & 0.6 & 8 \\
\hline FRRH & Frustulia rhomboides (Ehrenberg) De Toni & 3.4 & 12.2 & 0.5 & 5 \\
\hline GYKU & Gyrosigma küetzingii (Grunow) Cleve & 7.1 & 28.0 & 0.5 & 19 \\
\hline NACT & Navicula cryptotenella Lange-Bertalot & 16.4 & 54.8 & 0.9 & 38 \\
\hline NADI & Navicula digtoradiata (Gregory) Ralfs & 12.5 & 40.2 & 1.2 & 10 \\
\hline NAPE & Navicula peregrina (Ehrenberg) Kützing. & 2.7 & 9.1 & 0.5 & 18 \\
\hline NARH & Navicula rhynchocephala Kützing & 6.2 & 29.8 & 0.3 & 43 \\
\hline NASA & Navicula salinarum Grunow & 5.8 & 18.1 & 0.4 & 14 \\
\hline NEBS & Neiduim bisulcatum var. subampliatum Krammer & 17.1 & 46.8 & 0.6 & 4 \\
\hline NISI & Nitzschia sigma var. intercedens Grunow & 2.2 & 6.6 & 0.5 & 33 \\
\hline ODAU & Odontella aurita (Lyngbye) Agardh & 3.1 & 19.9 & 0.5 & 40 \\
\hline PILA & Pinnularia lagerstedtii (Cleve) Cleve-Euler & 3.4 & 11.9 & 0.5 & 11 \\
\hline PISU & Pinnularia subrabenhorstii Krammer & 8.5 & 16.5 & 0.7 & 5 \\
\hline PIVI & Pinnularia viridis (Nitzsch) Ehrenberg & 4.1 & 16.5 & 0.6 & 13 \\
\hline PLDE & Planothidium delicatulum (Kützing) Round et Bukhtiyarova & 8.0 & 29.7 & 0.4 & 53 \\
\hline PLLA & Planothidium lanceolatum (Brébisson) Round et Bukhtiyarova & 12.2 & 63.8 & 0.5 & 11 \\
\hline PLPU & Pleuosigma pulchrum Grunow & 3.5 & 15.4 & 0.6 & 15 \\
\hline PVEL & Pinnunavis elegans (W.Smith) Okuno & 2.8 & 10.4 & 0.4 & 10 \\
\hline SCTU & Scolioneis tumida (Brébisson ex Kützing) D.G.Mann & 11.0 & 37.3 & 0.3 & 51 \\
\hline SEPU & Sellaphora pupula (Kützing) Mereschkowsky & 4.6 & 16.4 & 0.3 & 4 \\
\hline SUFA & Surirella fatuosa (Ehrenberg) Kützing & 1.4 & 5.3 & 0.4 & 32 \\
\hline TRCC & Tryblionella compressa (Bailey) Boyer & 2.5 & 10.7 & 0.3 & 32 \\
\hline TRGR & Tryblionella granulata (Grunow) D.G.Mann & 6.6 & 22.5 & 0.4 & 36 \\
\hline
\end{tabular}

\footnotetext{
${ }^{1}$ Used in ordination diagrams based on CCA (Fig. 6).

${ }^{2}$ Average abundance in all samples.

${ }^{3}$ Maximum abundance in all samples.

${ }^{4}$ Minimum abundance in all samples.

${ }^{5}$ Number of stations at which occurred.
} 
Table 2. Results of CCA from diatom assemblages from modern samples at Akkeshi and Onnetoh sites.

\begin{tabular}{|c|c|c|c|}
\hline Axes & 1 & 2 & $\begin{array}{l}\text { Total } \\
\text { inertia }\end{array}$ \\
\hline Eigenvalues & 0.798 & 0.233 & 9.198 \\
\hline $\begin{array}{l}\text { Cumulative percentage variance } \\
\text { of species data } \\
\text { of species-environment relation: }\end{array}$ & $\begin{array}{r}8.7 \\
42.9\end{array}$ & $\begin{array}{l}15.1 \\
74.6\end{array}$ & \\
\hline
\end{tabular}

Sum of all unconstrained eigenvalues

9.198

Sum of all canonical

eigenvalues

1.860 
Table 3. Statistics summary of the performance of weighted averaging partial least squares (WA-PLS) for elevations (data set without Paralia sulcata and P-valves of Cocconeis scutellum).

\begin{tabular}{rrrr} 
Component & \multicolumn{3}{c}{ RMStimated errors } \\
& 1 & 0.2554 & R-squared \\
2 & 0.2075 & 0.8763 \\
3 & 0.1759 & 0.9183 \\
& & \\
& \\
Prediction errors & \\
& RMSEP & R-squared \\
1 & 0.2963 & 0.8335 \\
2 & 0.2884 & 0.843 \\
3 & 0.3025 & 0.8288
\end{tabular}


Table 4. Radiocarbon Ages on Macro-plant Fossils (after Sawai et al., 2002)

\begin{tabular}{|c|c|c|c|c|c|c|}
\hline $\begin{array}{l}\text { Elevation }^{6} \\
\quad(\mathrm{~cm})\end{array}$ & Material & Position & Type of contact & $\begin{array}{c}\text { Age }\left({ }^{14} \mathrm{C} \text { yr }\right. \\
\text { B.P. })\end{array}$ & $\begin{array}{l}\text { Age (cal yr } \\
\text { B.P.) }\end{array}$ & Lab no. \\
\hline $41-38$ & $\begin{array}{l}\text { Cone scale of } \\
\text { Picea glehnii }\end{array}$ & Above & $\begin{array}{l}\text { Abrupt, } \\
\text { peat/mud }\end{array}$ & $400 \pm 50$ & $523-315$ & Wk-9727 \\
\hline $28-32$ & $\begin{array}{l}\text { Leaf of Osmunda } \\
\text { cinnamomea }\end{array}$ & Above & $\begin{array}{l}\text { Contrast in } \\
\text { diatom } \\
\text { assemblages }\end{array}$ & $1360 \pm 60$ & $1350-1174$ & Wk-9884 \\
\hline$-163--158$ & $\begin{array}{c}\text { Seeds of } \\
\text { Polygonum sp. }\end{array}$ & Above & $\begin{array}{l}\text { Gradual, } \\
\text { peat/mud }\end{array}$ & $1950 \pm 60$ & 2001-1733 & Wk-9726 \\
\hline
\end{tabular}

Relative to the present mean tide level at Onnetoh site.

2 Range at two standard deviations, given by the calibration data of Stuiver et al. (1998) and the calibration software CALIB 4.1 of Stuiver and Reimer (1993). An error multiplier was 1.0. 


\section{Figures}

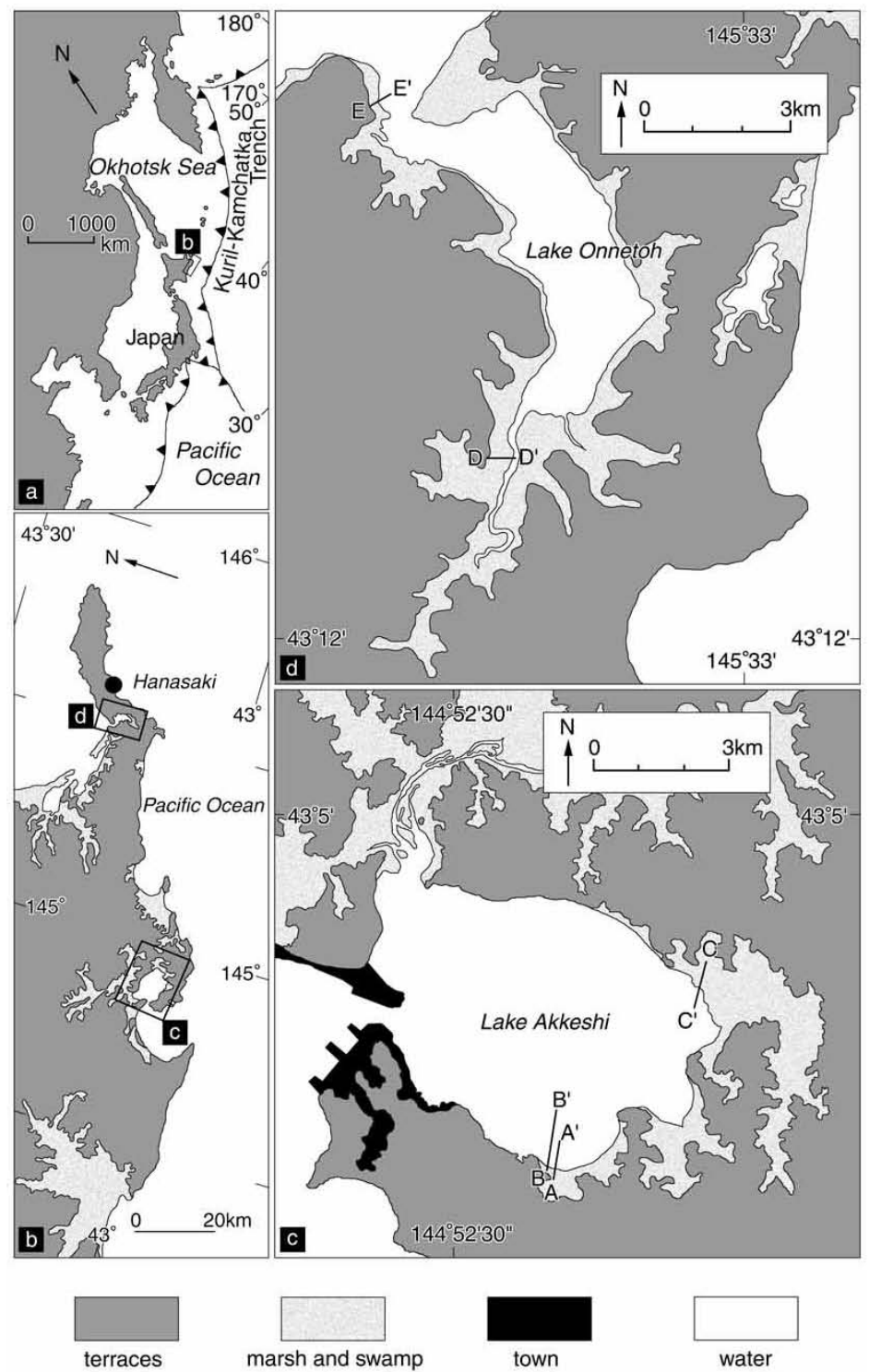

Fig. 1. Location of four transects. a: Plate tectonic setting. Solid line with triangles shows seaward edge of the subduction-zone. b: eastern Hokkaido, showing Akkeshi (quadrilateral c), Onnetoh (quadrilateral d), and Hanasaki. c: Locations of sampling transects in Akkeshi. d: Locations of sampling transects in Onnetoh. 

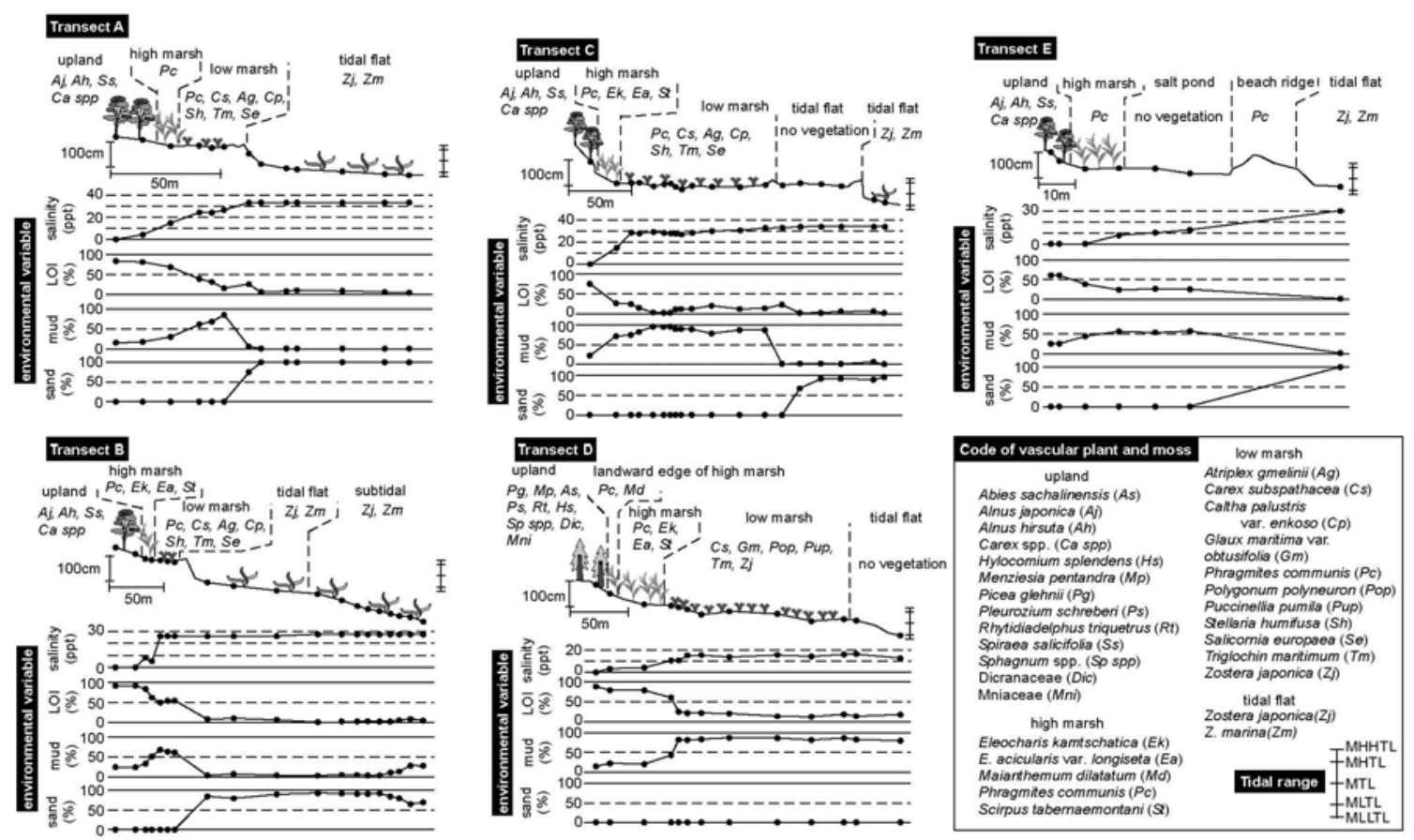

Fig. 2. Vascular plants and moss zonations at Akkeshi and Onnetoh estuaries. The environments of the transects were divided into upland, high marsh, low marsh, and tidal flat. Vascular plants and moss form their zonations relating to tidal level on the environments. Detailed compositions of assemblages are described in the text. 


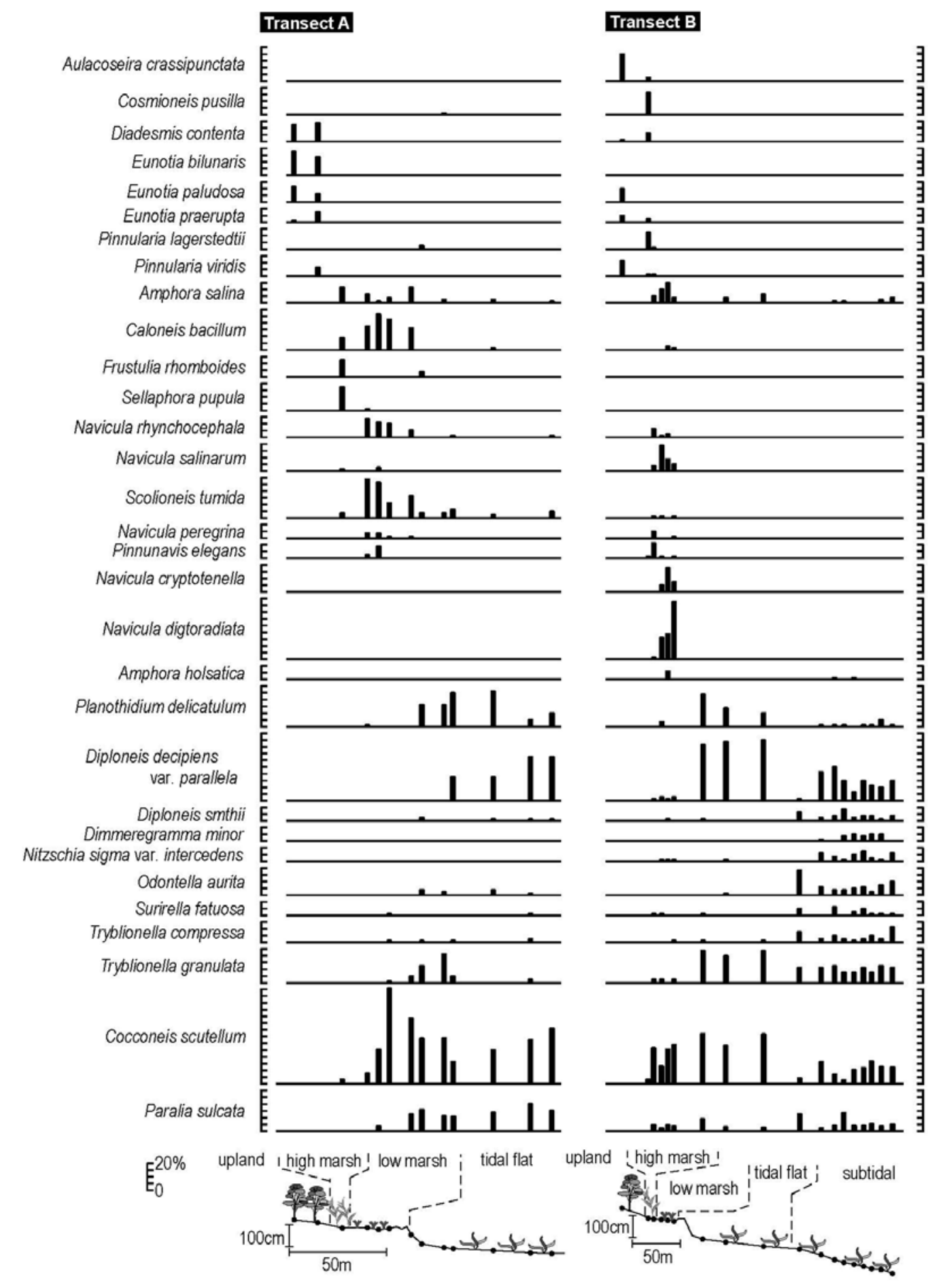

Fig. 3. Changes in dominant diatom species (exceeding 5\% relative to total diatom valves counted excluding Paralia sulcata and P-valves of Cocconeis scutellum) on transects A and B. Only Paralia sulcata and Cocconeis scutellum are expressed as TDV. 

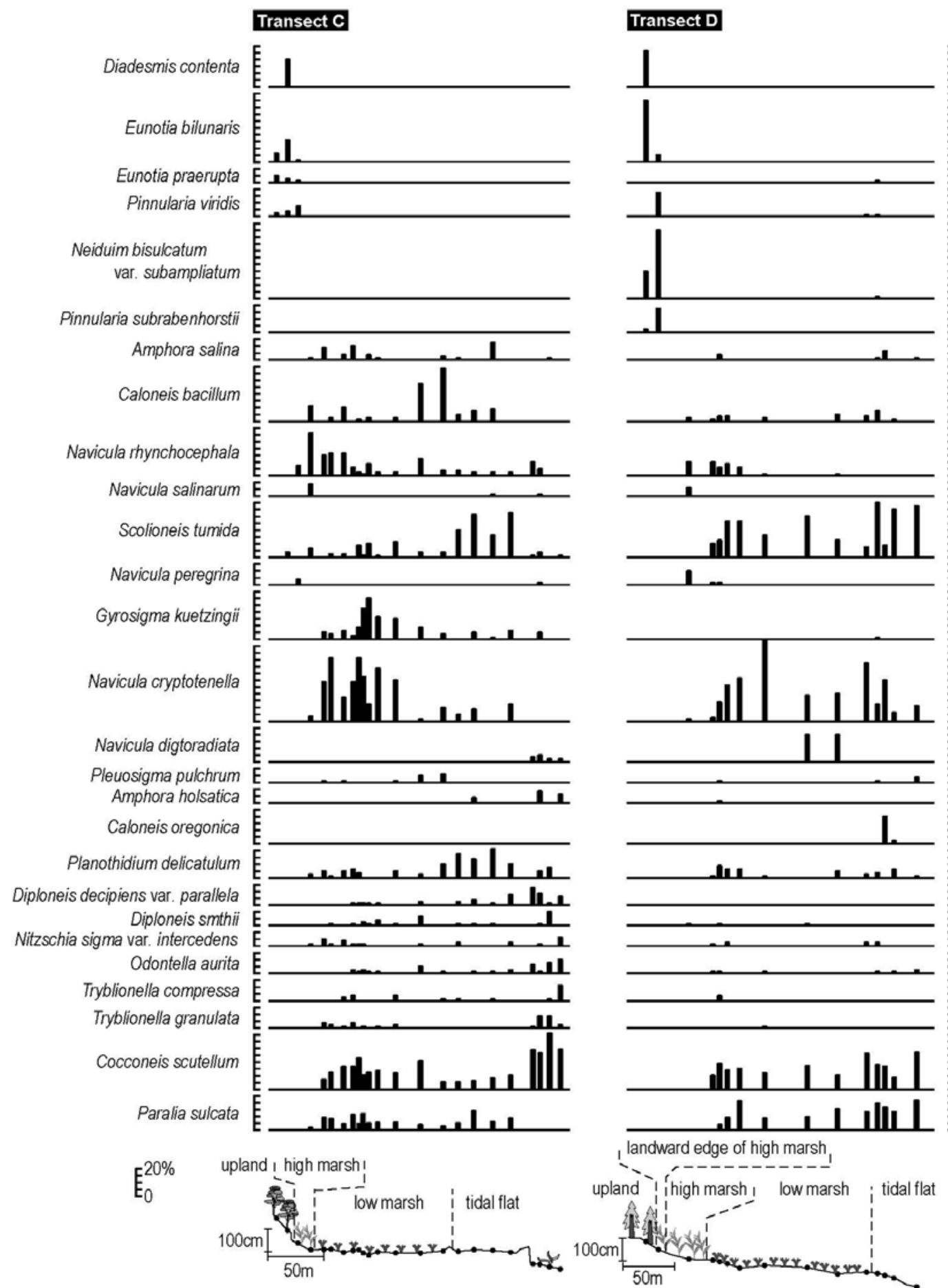

I landward edge of high marsh,

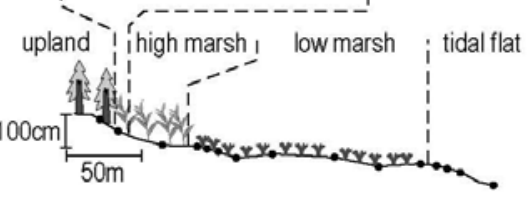

Fig. 4. Changes in dominant diatom species (exceeding 5\% relative to total diatom valves counted excluding Paralia sulcata and P-valves of Cocconeis scutellum) on transects C and D. Only Paralia sulcata and Cocconeis scutellum are expressed as TDV. 


\section{Transect E}

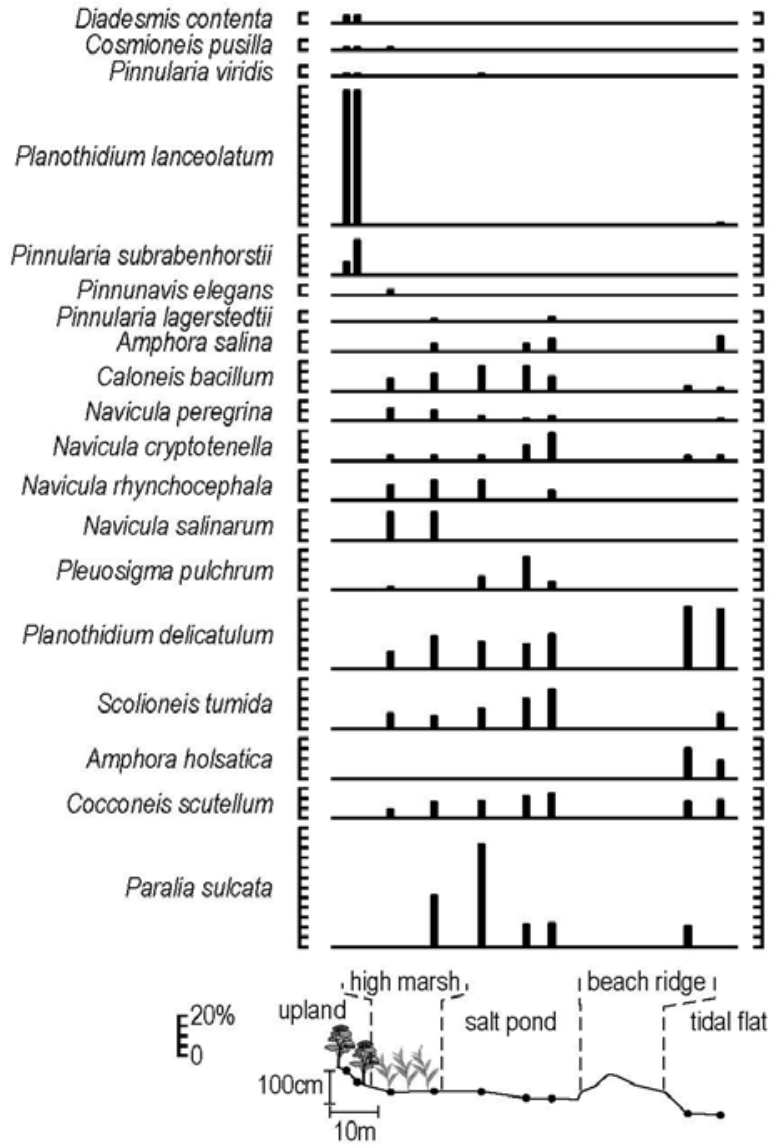

Fig. 5. Changes in dominant diatom species (exceeding 5\% relative to total diatom valves counted excluding Paralia sulcata and P-valves of Cocconeis scutellum) on transect E. Only Paralia sulcata and Cocconeis scutellum are expressed as TDV. 

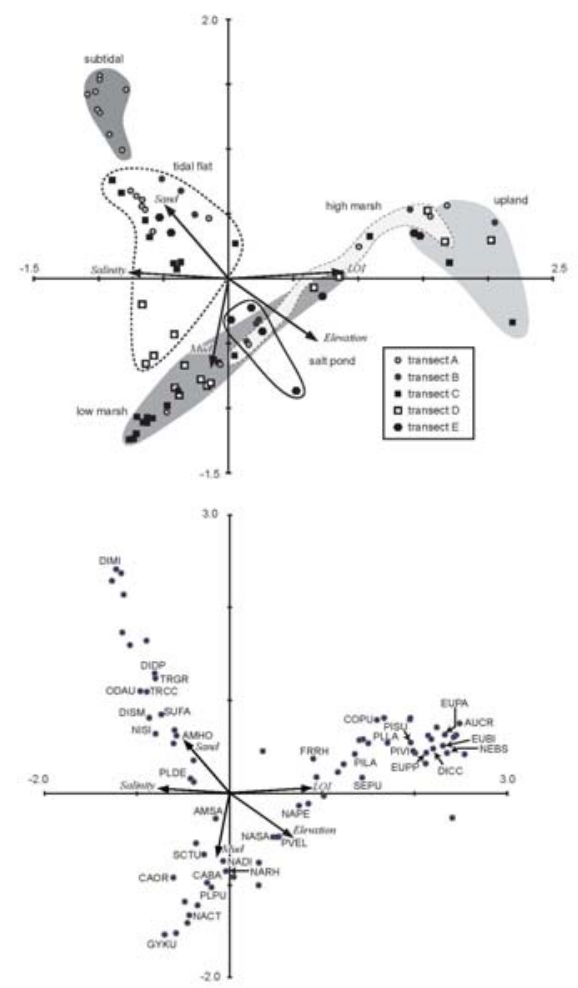

Fig. 6. Ordination diagrams for (a) sample stations and (b) species based on canonical correspondence analysis (CCA) of eastern Hokkaido diatom data. Five environmental variables (elevation, salinity, LOI, sand fractions, and mud fractions) are shown by arrows. CCA is based on TDV data set. Species codes are indicated in Table 2. 

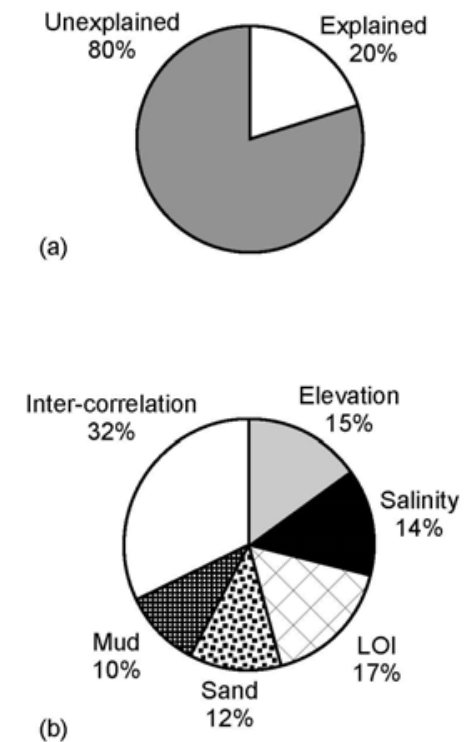

Sawai et al., Fig7

Fig. 7. Pie charts showing percentages of the total variances of the diatom data sets from eastern Hokkaido: (a) shows explained and unexplained portions; and (b) components represent the contributions of elevation, salinity, LOI, sand fractions, mud fractions, and intercorrelation among gradients. 
(a)

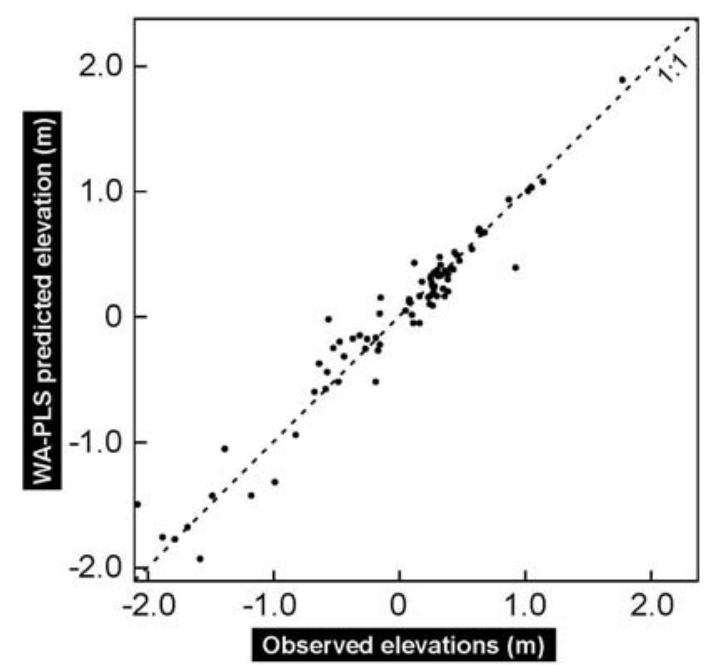

(b)

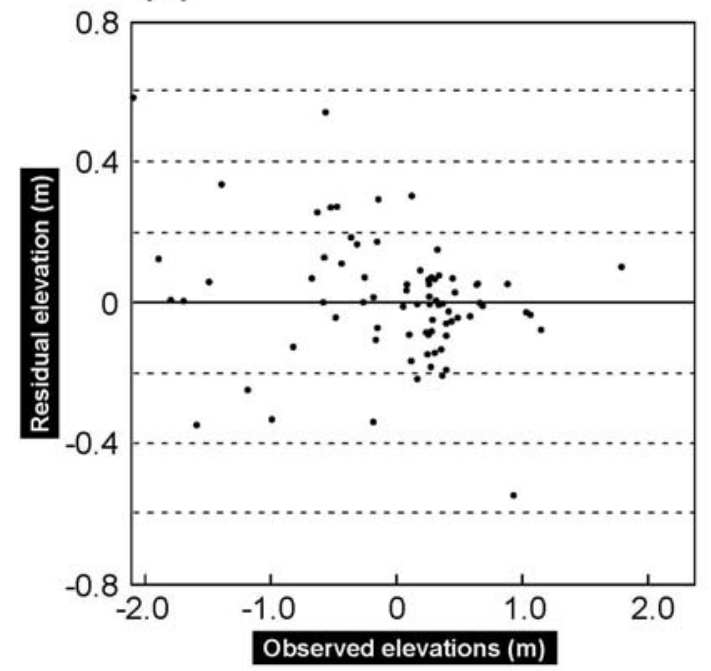

Fig. 8. Graphs of calibration results: (a) Scatter plots; and (b) residuals of WA-PLS predicted elevation versus observed elevations 


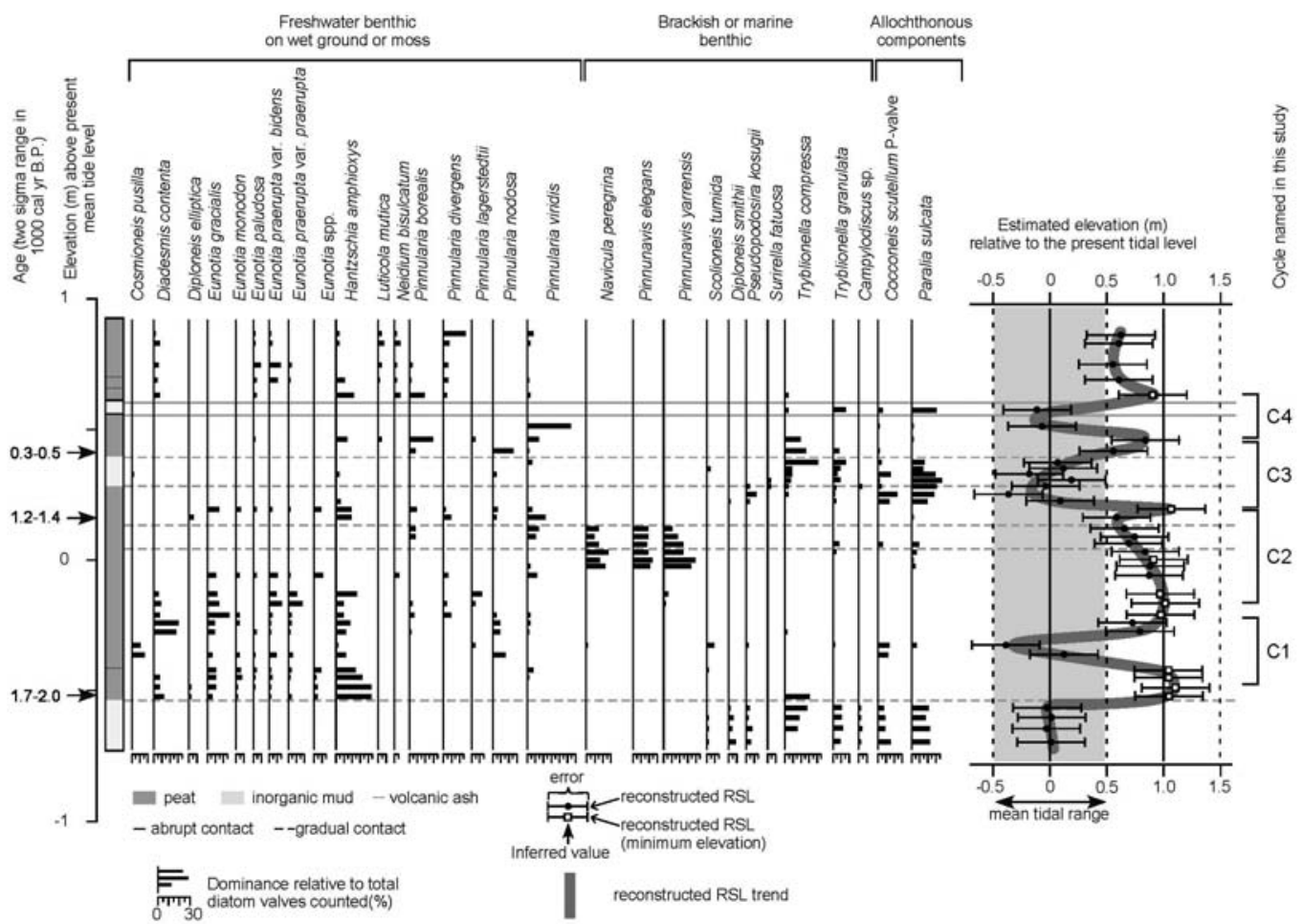

Fig. 9. Fossil diatom assemblages and results of weighted averaging partial least squares (WA-PLS) for elevations. Only dominant species $>5 \%$ TDV are shown in the diagram. Three radiocarbon ages were obtained from macro plant fossils above the contacts between marine-brackish mud and peat and overlying freshwater peat (following Sawai et al., 2002). Thick line in right column shows reconstructed elevation trend. Reconstructed values with arrows $(>0.85 \mathrm{~m})$ possibly show lower elevations because Diatom-based transfer functions with freshwater samples can underestimate the elevation (see text). 